\title{
CrimRxiv
}

\section{Trusting the Police:}

Comparisons across

\section{Eastern and Western}

\section{Europe}

\section{Silvia Staubli}

Published on: Mar 06, 2022

License: Creative Commons Attribution 4.0 International License (CC-BY 4.0). 
